\title{
Oopheid van hart - die kroon op die lewensarbeid van H.G. Stoker (4 April 1899 - 16 Mei 1993)
}

\author{
A.W.G. Raatl \\ Departement Regsfilosofie \\ Universiteit van die Oranje-Vrystaat \\ BLOEMFONTEIN
}

\begin{abstract}
With the death of Prof. H.G. Stoker, formerly lecturer in Philosophy at the PU for CHE, Calvinist philosophy has lost one of its greatest sons. Not only did Prof. Stoker develop a unique philosophy namely the Cosmocreatedness of the universe hut over more than five decades he published extensively in most fields of science.

In 1981 Prof. Shoker was awarded an honorary chair at his alma mater. In a series of lectures Prof. Sioker subsequently developed his basic philosophical views on the role of (.hristian openness in science and philosophy. His lecture on openness of the heart in Calvinist philosophy deals with love, faith and hope as the most findamental issues of life and the role of these in his Christian philosophy.
\end{abstract}

\section{Proloog}

\subsection{H.G. Stoker - ere-professor aan die PU vir CHO}

In vele opsigte het H.G. Stoker sinonien geword met die wysgerige denkwerksaanheid aan die PU vir CHO vanaf 1923 tot 1970. Vir sy lewensarbeid is prof. Stoker telkens bekroon. I Ook sy alma mater, die PU vir CHO, het benewens 'n

I Kyk H.G. Stokcr-versameling (HGSV): "Biographical Notes on Prof. Dr. H.G. Stoker": biografiese besonderhede deur prof. Stoker aan prof. W.N. Coctzee, dekaan Fakulteit Letter en Wysbegecrte (10.02.1971): G. Dekker. "Hendrik Stoker as mens, huldeblyk met prof. Stoker se vyf-en-scstigste verjaarsdag $(04.04 .1964) "$ ": ongedatecrde lewenskets "Rektor van dic ecrtydse 'Kofficfonteinse Universitcit" in die PU Kaner; biograficse notas aan prof. B. Duvenage vir dic huldigingsbundel Waarheid en werklikheid; biografiese notas aan prof. T.T. Clocte (18.05.1975) en "Vita Academica of Professor Dr. Hendrik G. Stoker". getikte manuskriptc. 
eredoktorsgraad in Wysbegeerte in 1971, in 1975 'n gereelde huldigingslesingreeks ingestel, verbind aan die naam van dié merkwaardige Calvinistiese wysgeer. In die PU Kaner van 12 September $1975^{2}$ is die volgende motivering vir die vererende optrede gestel:

Prof. Stoker se naam is aan die lesingreeks verbind omdat hy die grondlegger van die departement Wysbegeerte aan die PU vir CHO was. Hy was vanaf 1925 tot 1969 verbonde aan die departement Wysbegeerte. Prof. Stoker is internasionaal bekend as wysgeer en die huldigingsreeks is ' $n$ blyk van waardering vir sy dienste.

By die eerste lesingsreeks het prof. Henk Hart van Toronto, Kanada, teruggekyk hoe Stoker saam met Dooyeweerd en Vollenhoven grondleggers was van die Calvinistiese wysbegeerte. Hy het voorts hulde gebring aan die belangrike bydrae wat prof. Stoker gelewer het as kampvegter vir Christelike wetenskap. ${ }^{3}$

Vyf jaar later, op 9 Desember 1980, rig die registrateur van die PU vir CHO, prof. E.J. Smit, 'n brief aan prof. Stoker waarin hy hom meedeel dat die Raad van die Universiteit eenparig besluit het om hom met ingang 1 Januarie 1981 as ereprofessor in die Departement Filosofie te benoem. ${ }^{4}$

Op 24 April 1981 het prof. Stoker sy ereprofessorale intreerede in die Konservatoriumsaal van die Universiteit gelewer. ${ }^{5}$ Die PU Kaner het die intreerede soos volg beskryf:

Christen-wetenskaplikes stel dikwels dat die doel van Christelike wetenskapsbeoefening is om God te eer en te verheerlik. Dit is korrek, sê prof. Stoker, maar dit is heeltemal onvoldoende. Alle menslike taakbehartiging behoort te geskied tot eer en verheerliking van God, nie net wetenskap nie. ${ }^{6}$

Die berig lui voorts:

Op die vraag wat die doel van die wetenskap is, stel prof. Stoker voor dat daar uitgegaan word van Ef. 3:10, nl. die gedagte van die veelkleurige wysheid van God. Die wetenskaplike moet hom dit ten taak stel om so indring-

$2 \quad$ Op 2 .

3 Ibid.

4 HGSV, brief E.J. Smit - H.G. Stoker, 09.12.1980.

5 Kyk PU Kaner, 19.06.1981:2.

6 Ibid. 
end en omvattend moontlik die veelkleurige wysheid van God in die skepping te openbaar. ${ }^{7}$

\subsection{Die oopheidslesings}

Gedurende 1981 het prof. Stoker uit hoofde van sy ereprofessorale benoeming ' $n$ reeks lesings oor 'oopheid' in die wetenskap gelewer. Prof. Stoker se lesings het onder andere gehandel oor 'oopheid' met betrekking tot eenders- en anders-kennendes; ontiese 'oopheid'; harte-'oopheid'; historiese 'oopheid' en sosiale 'oopheid' 8

Met as tema oopheid van die hart het prof. Stoker die wetenskap as spesifiekmenslike aktiwiteit onder die soeklig geplaas. Omdat alle wetenskappe van 'n mensbeskouing uitgaan, moet die mens hom ook verantwoord oor wie en wat die mens is. Vanuit die perspektief van die Skeppingswysbegeerte sien Stoker die mens as 'n kreatuurlike, kosmiese wese wat na die beeld van God geskape is. As beeld van God is die mens ook onder meer heer van die skepping. Met verwysing na die tema oopheid van hart het Stoker die Skrifperspektief gebruik dat alle uitgange van die lewe uit die hart is. ${ }^{9}$ Hy het vir 'n oopheid tot hierdie lewensuitgange gepleit.

In sy samevatting en bedanking het prof $B$. Duvenage gesê dat weinig filosowe op 82-jarige ouderdom in staat sou wees om so 'n lesing te kon lewer. 10

Met hierdie lesing het prof. Stoker as't ware die kroon gespan op sy verbondenheid met sy alma mater en sy akademiese loopbaan op 'n hoogtepunt afgesluit.

Dit is met 'n tikkie weemoed dat 'n mens die gelukwense van sy ou vriend en kollega, Zeller (prof. S.P. van der Walt), in 'n brief van 26 Maart 1981 lees:

$U$ benoeming tot ere-professor aan ons Universiteit vervul my met dankbaarheid, innige dankbaarheid. Daar is min professore wat daarin slaag om nie net hulle eie standpunte te stel nie, maar hulle studente te inspireer om saam te dink en selfstandig te dink. Die Here het $u$ die vermoë gegee om telkens duidelik te stel dat dit te vroeg is in die Christelike wysbegeerte om 'n geslote sisteem te vorm. Dit moet nog oop bly om nuwe Christelike

$7 \quad$ Ibid.

8 HGSV, knipscl uit Die Wapad, 25.09.1981.

9 Ibid.

10 Ibid 
gedagtes te kan akkommodeer en te integreer. Vir my was dit dikwels 'n inspirasie. 11

\subsection{Die oopheidslesings en Stoker se metodiese benadering}

Kort na die verskyning van Stoker se monografie Die Wysbegeerte van die Skeppingsidee in 1933, is hy in Nederland deur ' $n$ akademikus gevra:

"My liewe prof. Stoker, Dooyeweerd gaan van 'n idee uit: die wysbegeerte van die wetsidee, maar idee is iets wat 'n mens het. Waarom praat jy van die wysbegeerte van die skeppingsidee? Waarom praat jy nie doodeenvoudig van skeppingswysbegeerle nie?"12

Die idee-komponent van Stoker se wysbegeerte het hy nooit idee-isties bedoel nie; skeppings-idee het hy onties vertolk vir sover hy onties op die skepping gefokus het. Só sterk het Stoker oor dié nuanseverskil in sy filosofie gevoel dat hy in die vroeë tagtigerjare verklaar het:

Maar ek stem toe. Ek moes daardie woord 'idee' nooit gebruik het nie. As ek my filosofie in Engels vertaal, sal ek dit nie noem die idee van die kosmos nie, ek sal dit noem 'n 'cosmo-created philosophy'. Maar, jy het 'n grondgedagte nodig wat die kosmos in sy eenheid saamvat en dit doen die skeppingsgedagte. ${ }^{13}$

Hiermee tree Stoker se sensitiwiteit vir 'n benadering aan die lig wat die neoKantiaanse reste van menslike idee-matigheid mis; ' $n$ benadering wat 'faneroties', 'onties' meer oop staan om die veelkleurige wysheid van God in die skepping tot openbaring te bring. ${ }^{14}$ Dit was een van die belangrikste redes vir sy kritiek teen die wysbegeerte van $\mathrm{H}$. Dooyeweerd se transendentale metode. Stoker se standpunt was dat indien die transendentale metode gebruik word, dan moet 'n punt gevind word vanwaar uitgegaan kan word om alles te oorsien. Hierdie punt impliseer 'n posisie vanwaar jy, as méns, kan uitgaan om alles te oorsien, want jy, as méns wil dit immers oorsien. Dié punt vind Dooyeweerd, volgens die Kantiaanse transendentale metode, in die ék, wat hy reduseer tot die hart in Skriftuurlike sin. Stoker verklaar:

II HGSV, bricf Zeller - H.G. Stoker, 26.03.1981.

12 HGSV, bandopname verw. A.2.1.8.2.

13 Ibid.

14 Ibid. 
En dan kan ek sien hoe is my ervaring moontlik; ek het iewers 'n archimedespunt nodig. Dan is die vind van ' $n$ Archimedespunt, soos by die Kantiane orals gesoek word, ' $n$ uiters belangrike iets. ${ }^{15}$

Stoker se vertrekpunt neem hy in Genesis 1:1;16 hierin vind hy die nodige eenheidsgrondslag en as sodanig sou hy nie 'n Archimedespunt, oftewel binnekosmiese sentrum nodig hê nie; sou 'n kosmosentriese punt nie nodig wees van waaruit alles oorsien hoef te word en dan nog God ook daarby te betrek deurdat die hart na God moet wys nie. Dit alles getuig van 'n humanistiese benadering waarvolgens alles vanuit die mens, deur die mens en tot die mens is, behalwe dat die mens ' $n$ skepsel van God is.

Die tweede probleempunt in Dooyeweerd se filosofie, wat met die voorgaande verband hou, het Stoker gesien in die plek wat Dooyeweerd aan die hart toeken in die totaliteit van die kosmos. ${ }^{17}$ Dat die hart op een of ander wyse die eenheid van die mens met sy verskeidenheid van funksies, aktes en strukture waarborg, het Stoker aauvaar. Ook het hy saamgestem dat dié eenheid nie gesien mag word in die vorm-materie-skema nie, ook nie in die skema van geheel en dele nie, soos byvoorbeeld gegee in die strukturele eenheid van stof, plant, dier en mens nie. ${ }^{18}$

Die verhouding van die eenheid deur die hart gegee (wat uit al die uitgange van die lewe is) tot die verskeidenheid waaraan die mens deel het, sien die Wysbegeerte van die Wetsidee, volgens Stoker, (a) as 'n transendensie van tyd en verskeidenheid, en (b) daarin dat die hart 'n konsentrasiepunt van die verskeidenheid is.

Die eerste bepaling bied, volgens Stoker, die probleem dat die hele mens, dus ook sy hart, in sonde geval het, dit wil sê verander het; dat verandering tyd veronderstel en die hart dus ook aan die tyd onderworpe moet wees. ${ }^{19}$

Met die tweede bepaling sou Stoker hom in 'n bepaalde opsig kon verenig, afhangend van wat onder konsentrasiepunt verstaan moet word. Hy sou wel kon saamstem indien met konsentrasiepunt bedoel word dat alle verskeidenheid van en in die mens aan ' $n$ ' $e k$ ' behoort en onder leiding van die 'ek' staan (of behoort te staan), dat die 'ek' die kardinale eenheid aan die mens gee in 'n ander sin as

Ibid.

Kyk bv. Stoker, 1970a:202-330.

17

HGSV, bandopnames nrs. $21 \mathrm{cn} 22$.

18

Ibid

19

Ibid. 
wat die geheel-dele-skema dit doen en ook so dat daar geen grenslyn (soos byvoorbeeld die tyd) tussen die ek en die verskeidenheid van en in die mens bestaan nie.

Naas en benewens die transendentale metode het Stoker se appèl uitgegaan van 'n sensitiwiteit vir die verband tussen mens en kosmos; vir die 'fanerotiese' bo die funksionele en die ontiese bo Kantiaanse transendensie, om die veelkleurige wysheid van God in die skepping bloot te lê. Met die diafanerotiese metode van Wesenschau het Stoker die 'fanerotiese' band tussen mens en skepping blootgelê, ontwaar, deurskou; het hy daarop gewys dat die fenomenologiese (diafanerotiese) metode, die metode van Wesenschau, nie onlosmaaklik verbind is met die onderstellings wat Scheler en Husserl (elk op sy eie wyse) daaraan ten grondslag lê nie en dat hierdie metode ook sy onmisbare plek in die Calvinistiese wysbegeerte het. 20

Die 'fanerotiese'/"ontiese' sensitiwiteit vir die skepping van God in die metode van Stoker, kom tot volle wasdom in sy voordrag oor 'oopheid van hart'. Vir die Christelike wetenskap is dit belangrik dat hierdie 'ryping' met mede-filosowe gedeel moet word.

\subsection{Publikasie van die oopheidslesings}

Daar bestaan ' $n$ lank gevoelde behoefte dat die oopheidslesings gepubliseer moet word. Miskien is dit juis nou ook belangrik, na die afsterwe van prof. Stoker, dat sy merkwaardige bydraes op hierdie terrein die lig moet sien. In die voorwoord van sy voordrag oor oopheid van hart het Stoker die belang van die oopheidslesings en die verband tussen hierdie 'oopheidskomponente' soos volg gestel:

In my inougurele rede het ek 'n paar punte genoem wat ek weer sal moet herhaal om aansluiting te vind. Ek het daar geëindig met die ontiese oopheid. Dan is daar die harte-oopheid wat ek nou gaan behandel. Uiters belangrik is die historiese oopheid in die Christelike wetenskapsbeoefening en dan veral ook die sosiale oopheid. Dit is nie al. Daar is ander oophede ook. Een oopheid wat ek vreeslik graag in verband met wetenskap sou wou behandel is die wonderlike oopheid van verbeelding. 21

20 Stoker, 1970a:418 voetnoot 20 voeg hicr by: "In my vroeëre werke het ck van 'wesc' en 'wesenskou' geskryf, maar dit nie in Husserl-Scheleriaanse fenomenologicse sin bedoen nie. Omdat ek hier dieselfde terme gebruik as in dic fenomenologic, het Malan my misverstaan. Dat ek in my vrocëre werke nic (in elk geval nie voldoende) die verskil tussen Scheler en my uitgebring het nic, erken ek as 'n tekort. Ook het ek later die verskil skerper leer insien as voorheen. Maar my latere werke mag nie van hierdic tekort dupe gemaak word nic." 
Die lesings oor oopheid is onder die tema van "wetenskap en oopheid" in die Stoker-versameling van ds. Henk Stoker op band opgeneem 22 en per hand getranskribeer. Die weergawe van "harte oopheid" wat hiema volg, is vanaf ds. Stoker se bande getranskribeer en in geredigeerde vorm verwerk. Die inhoud van die voordrag is deur die outeur (AWGR) geredigeer en van verklarende voetnote, waar nodig, voorsien. Opmerkings van prof. Stoker is tussen hakies [] in die voetnote opgeneem.

Vir Stoker was dit belangrik dat hy oor die kwessie van oopheid van hart korrek verstaan moes word. Hy verklaar:

Ek gaan sommer van hart tot hart praat, sonder om tegniese begrippe te gebruik of ten minste op ' $n$ tegniese manier te verduidelik. Ek wil graag verstaan word.

Hy voeg by:

Maar ek doen dit in die gees van K.J. Popma. Hy het in een van sy werke in die begin geskrywe: Ek weet nie of ek hier nou as gelowige praat, of ek uit my lewens- en wêreldbeskouing praat, ek weet nie of ek teologiseer en ek weet nie of ek filosofeer en ek weet nie of ek vakwetenskaplik praat, maar ek sien ' $n$ probleem en ek praat, met ander woorde sonder ' $n$ tegniesmeganiese afbakening van dit hoort in dié wetenskap tuis en dát hoort in dáárdie wetenskap tuis; ' $n$ oop gesprek, hart tot hart; visionêr. ${ }^{23}$

\section{Harte-oopheid: die voordrag van H.G. Stoker}

\subsection{Inleidend}

\subsubsection{Die viervoudige betekenis van Christelik}

In die eerste plek praat ons van Christelike wetenskap. ${ }^{24}$ As u nie weet wat ons met Christelik bedoel nie, sal u ook nie verstaan wat ons met Christelike wetenskap bedoel nie. U sal die idee van die noodwendigheid van ' $n$ Christelike weten-

22 HGSV, bandopnames nrs. 21 en 22 .

23 Ibid.

24 Aanvanklik het Stoker die nuanse van Christelike wetenskap wat hy voorstaan tetsfiese filosofie genocm; vgl. Stoker 1927(a) en 1927(b). Vanaf ongeveer 1930 het hy dit die Wysbegeerle van die Skeppingsidee genocm, vgl. Stoker 1932, 1933(a), 1933(b), 1941. Deurentyd het hy egter nouc bande met cksponente van dic Wysbegeerle van die Openbaringsidee ( $\mathrm{H}$. Bavinck en V. Hepp) bchou, asook met filosowc uit dic kaders van die Wysbegeerte van die Wetsidee (D.H.Th. Vollenhoven en H. Dooyewecrd). 
skap veral aantref in die lyn van Calvyn tot die kring rondom die stigting van die Vrije Universiteit in 1880, wat sedertdien wêreldwyd versprei het. ${ }^{25}$

Hierdie rigting gaan radikaal uit van 'n absolute teosentrisiteit van alle dinge. En wat Christus betref, nie net as Verlosser, maar ook as Herskepper. En wat die Heilige Gees betref, nie net as openbarende werksaamheid in sy Woord, maar ook as openbarende werksaamheid in die presensie Gods in die skepping. Uit, deur en tot God is alle dinge, terwyl die ander rigtings hoofsaaklik gekenmerk word deur 'n dualisme: geloof en rede; teologie en filosofie, natuur en genade; kerk en maatskappy ensovoorts. Ons wil daardie dualisme die nek inslaan; by die wortel afsny.

Daar is ' $\mathrm{n}$ tweede betekenis van Christelik. Jy kan die woord Christelik beperk tot die Christelike handelinge in die kerklike gemeente, huisgodsdiens, binnekamergebed. ${ }^{26}$ In die engere spesifieke betekenis van Christelik bedoel ons nie Christelike wetenskap nie. Die belydenis van die gemeente van die artikels van die geloof is geen wetenskaplike betoog nie. En as ' $n$ skeikundige of ' $n$ ander wetenskaplike brood en wyn analiseer, het dit niks met Nagmaal te doen nie.

Tweedens is daar die term Christelik in die alomvattende sin dat die mens in alles wat hy doen en laat van God 'n roeping ontvang het - 'n roeping wat hy as medearbeider Gods hier op aarde moet vervul tot eer en verheerliking van God. ${ }^{27}$ In hierdie omvattende roepingsvervullende diens van God bedoel ons Christelik as ons van Christelike wetenskap praat.

25 ["Dus in die lyn van Calvyn. Ek beskou dat dit dic juiste lyn is; maar my kollega prof. Carel Oberholzer van Pretoria sê nee ons is verkecrd: dit wat ek Calvinisme noem, is in Kuyperiaans-georiëntecrde Nco-Calvinisme. Dan sê ck vir hom: 'My liewe Carel, jou Calvinisme is 'n skolasticse dualisticse Calvinisme'. En ons sê dit met die grootste vriendelikheid an mekaar. Maar laat ons dit darem seker wect, dic lyn wat ons volg, is van Calvyn tot wat die stigters (of hulle dit hecltemal reg gesê het of nie reg gesê het, laat ck daar) van dic Vrijc Universitcit bedocl het, wat van daaruit tot vandag toc oor al dic kontinente van die wêreld versprei het."I

26 ["Popma kwalifiseer dit as dic aanrocp van Gods naam. "]

27 Die roepingsgedagte staan in bepaalde opsigte sentraal in dic wysbegcerte van Stoker vir sover die mens van God ' $\mathrm{n}$ rocping ontvang het $\mathrm{en}$ waarop dic mens primêr, in verhouding tot God, antwoorder is. Kyk ook Oopheid in die wetenskap, HGSV, verw. 2.3.2.1: "Daar is ' $n$ godsdiens in engere sin, die gemeentelike bycenkoms, in dic huisgodsdiens, binnekamergebed wat jy kan saamvat met die woorde: 'Daar roep jy Gods naam aan'. Maar dan is daar in die tweede plek 'n diening van God in ruimer sin - God het dic mens hicr gestcl met 'n docl, met ' $n$ taak, met 'n rocping, en met alles wat hy doen en laat moet hỵ tot God se eer en verheerliking sy rocping vervul." 
In die derde plek is daar weer die heerlike twisprobleem tussen prof. C.K. Oberholzer en my. Daar is ' $n$ onderskeid tussen 'n Christelike beoefening van wetenskap en 'n beoefening van Christelike wetenskap. Prof. Oberholzer en ek aanvaar van harte ' $n$ Christelike beoefening van wetenskap, 'n beoefening van wetenskap met 'n Christelike moraal, 'n Christelike konsensieusheid en 'n Christelike getrouheid, ensovoorts, maar die beoefening van 'n Christelike wetenskap verwerp hy, want die wetenskap is nóg Christelik nóg on-Christelik. Myns insiens is die wetenskap wel deeglik Christelik. ${ }^{28}$

Die vierde onderskeiding is vir my die mees fundamentele. Ek het dit veral aan wyle prof. Jan van Wyk te danke. Ek wil dit hier noem. Ons het nog altyd 'n opvatting oor Christelike wetenskap gehuldig en hy het net die vraag gestel en ons het daar 'n drietal jare mee geworstel: moet ons naas die opvatting van Christelike wetenskap nie ook 'n Christelike opvatting van wetenskap huldig wat vir alle wetenskap geld nie? Ons is dankbaar dat ons daarop 'n antwoord gekry het. Dus in hierdie dubbele sin bedoel ons dan ook Christelike wetenskap.

\subsubsection{Anderskennendes}

Eerstens het ek in my inougurele rede ${ }^{29}$ in verband met anderskennendes gesê: anderskennendes is mense wat anders wetenskap bou as 'n Christen. Ek gaan dit nie verduidelik nie.

In die tweede plek, in sover daar 'n antitese is deur die kontekste waarbinne hulle die waarheidsmomente sien, moet ons oop wees om daardie kontekste, daardie ander standpunte te verstaan. Dit is moeilik om 'n ander man te verstaan - iemand wat anders dink as jy - hom reg te verstaan en nie sommer daarvan 'n paar modellyne te maak en dan met ' $n$ paar mokerhoue inmekaar te slaan nie. Jy moet hoin reg verstaan.

Maar dan in die derde plek (dis net so belangrik), daardie antitese van die anderskennende teenoor my, gekonfronteer daarmee, eis van my dat ek my eie kontekste, my eie oorsigte, my eie veronderstellinge krities hertoets en herwaardeer, want ek kan verkeerd wees. Dis oopheid van Christelike wetenskap.

28 Vir 'Christelike wetenskap' kyk Stoker, 1970a:53 voctnoot lla en dic bronne daar vermeld

29 Oopheid in die wetenskap, HGSV, verw. 2.3.2.1 


\subsubsection{Wetenskap: drie vrae}

\subsubsection{Wat is wetenskap met betrekking tot gewone kennis?}

Ek het ' $n$ onderskeid gemaak tussen gewone kenne en wetenskaplike kenne. Wetenskaplike kenne het ek spesifieke kenne genoem. Daar is gewone kuns (volksliedere, volksdanse) en daar is spesifieke kuns (van die kunstenaar); daar is gewone ekonomie in die huishouding van ' $n$ huisvrou en moeder en daar is spesifieke ekonomie van 'n beroepsekonoom; daar is die gewone vorming en uitbouing van kuns in die gewone lewe en dan is daar 'n spesifieke vorming en uitbouing van wetenskap. Wetenskap het as spesifieke taak die navorsende vorming en uitbouing van kennis, universeel, orals waar dit enigsins moontlik is. ${ }^{30}$

\subsubsection{Wat is die doel van wetenskap?}

Wat die doel van die wetenskap betref, kom ons by die vraag van Jan van Wyk met betrekking tot 'n Christelike opvatting van wetenskap in onderskeid van ' $n$ opvatting van Christelike wetenskap. Ek het die opvattinge van wetenskap ter wille van wetenskap verwerp; wetenskap ter wille van die verryking van die menslike gees en sy vreugde daarin verwerp; die opvatting van wetenskap ter wille van mag ensovoorts verwerp. Ek het gesê wetenskap tot eer en verheerliking van God is goed, maar nie goed genoeg nie. Kuns, ekonomie, politiek ensovoorts moet jy ook tot eer en verheerliking van God doen. Waarin moet die wetenskaplike die eer en verheerliking van God soek? Daar het ek aangesluit by Efesiërs 10:3 waarin dié pragtige woorde staan: "die veelkleurige wysheid van God".

God het in sy Woord, in sy skepping 'n veelkleurige wysheid gelê en die doel van die wetenskap is om die telkens nog verborge veelkleurige wysheid van God wat in sy skepping en Woord aanwesig is te onthul. Dit geld vir alle wetenskappe: of dit nou ' $n$ heiden is, ' $n$ Griek of ' $n$ Romein is, 'n Christen of ' $n$ Jood is; dit maak nie saak waar die wetenskaplike werk of wanneer hy werk nie; wat sy probleme is; dit maak nie saak of hy dit goed of sleg doen nie; of hy dit aweregs of regs doen nie. Alle wetenskap het as sy diepste sin die navorsende onthulling van die telkens nog verborge veelkleurige wysheid van God.

30 Hierdic omskrywing is meer toegespits as Stoker se meer 'formele' omskrywing van wetenskap in Stoker, (1969:137) synde "sovecl moontlik tegnies-metodics geverificcrde en sovecl moontlik tegnies-metodies gesistematisecrde kennis". 


\subsubsection{Van waaruit beoefen ons wetenskap?}

Die voorafgaande was 'n Christelike opvatting van wetenskap. Nou kom 'n opvatting van Christelike wetenskap, binne die fundamentele kontekste waarin ons as Christene ons veld van ondersoek sien; bimne die menswees van die mens; binne die mens en die samelewing; binne die mens en sy plek in die kosmos; binne die kosmos; binne die kosmos as 'n skepping van God; binne die verhoudinge van God tot kosmos en sy openbaringe daarvan; binne daardie kontekste ${ }^{31}$ sien ons ons veld van ondersoek en daar kry jy dan 'n opvatting van Christelike wetenskap en hier is alles onties oop. 32

\subsubsection{Ontiese oopheid}

Onties oop is die openbaring van God, ook vir die ongelowige - lees maar Romeine 1:19. Onties oop is die kreatuurlike van die kosmos en van die wetenskaplike en van die wetenskap wat alle -ismes verbied. Onties oop is die radikale verskeidenheid wat deur God as sodanig geskape is en hulle samehang ${ }^{33}$ wat alle antinomieë, reduksionismes en paradokse verbied. Onties oop is om eindelik deur te dring tot daardie wonderstruktuur van 'n samehang van 'n verskeidenheid wat radikaal verskillend is - iets wat jou verstand te bowe gaan.

Die doel van 'n beoefening van Cluristelike wetenskap is om met indringende navorsing, soveel as moontlik die wonderstruktuur van die kosmos bloot te lê; nie om die wonder weg te verklaar nie, maar om die wonder tot openbaring te bring.

\subsection{Oopheid van hart}

\subsubsection{Menslikheid van wetenskap}

As ek praat van die oopheid van hart in die wetenskap het $u$ te doen met die menslikheid van die wetenskappe. Ons moet altyd onthou - wetenskap is deur en

31 ["Ek kon amper Kuhn se woord gebruik, binne daardic 'paradigmas' as u wil."]

32 Dic gedagtes van oopheid, ruimheid, rykheid en ruimhartigheid van dic Christelike wetenskap het Stoker waarskynlik in 1964 begin uitbou. Kyk byvoorbecld sy refcraat voor dic stigtingskongres van dic Suid-Afrikaanse Vereniging vir die bevordering van Christelike Wetenskap te Pretoria op 04.09.1964.

33 Ibid.: "Christelike wetenskap is as wétenskap besonder ruim, ryk en ruimharig omdat dit oopstaan vir dic openbaring van God in sy Woord en dic lig wat dit op die kosmos en daarmec op dic betrokke velde van wetenskaplike ondersock werp, en dus ook oop vir dic kreatuurlikheid en onselfgenoegsaamheid van mens en kosmos; oop vir alles wat die kosmos bied, niks uitgesluit nie ...". 
deur menslik, kreatuurlik menslik, geheel en al menslik; sy probleme, metodes, kriteria, resultate is menslik.

Die volgende vraag kom egter na vore: Die mens inisieer die wetenskap, by die mens lê daar inisiatief maar wat is dit? Aan die ander kant: kragtens die mens se menslike bydrae dra hy by tot die wetenskap - wat is hierdie menslike bydrae tot die wetenskap? En dan ons probleem: hoe is hierdie menslikheid oop? Ons het hier te doen met die menslike faktor in die wetenskap en dan onderskei ek vier betekenisse van die menslike faktor. Ek behandel net een, maar dan moet ons al vier in die oog hou (daar kan baie meer wees).

Wat ek hier behandel, is die algemeen menslike faktor wat in alle menslike wetenskap aanwesig is. Dan kry jy die tweede, die persoonlike faktor - die rede waarom die verskil van persoon en persoon; verskil van aanleg en aanleg; van talent en talent; verskil van omstandighede, situasies, verskil van opvoeding en opleiding, sy invloed op die wetenskapsbeoefening het.

In die derde plek - een van die knellendste probleme in die huidige krisis van die wetenskap ${ }^{34}$ is dat die wetenskap vir die wetenskaplike 'n probleem geword het. Een van hierdie kernprobleme is die sosiale. Die sosiale aard van die wetenskap is ook ' $n$ persoonlike faktor, en die laaste faktor is dan die historiese.

\subsubsection{Die menslikheid van die wetenskap is vir alle wetenskappe van belang}

In die bespreking beperk ek my tot die algemeen menslike. Hier kry jy te doen met die algemene antropologie wat op hierdie vraag wetenskaplik wil antwoord. Ek wil as stelling poneer dat die mensopvatting voorwetenskaplik is en die wetenskaplike antropologie (antropologiese mensbeskouing) nie. Hierdie aanname is egter nie net van belang vir alle antropologie wat $u$ beoefen, naamlik fisiese antropologie, biotiese, fisiologiese, psigiese, sosiale, filosofiese, teologiese antropologie ensovoorts nie - hierdie uitgangspunt is van belang vir elke wet, want elke wet gaan implisiet van 'n mensbeskouing uit. Ons aanvaar dat die mens byvoorbeeld dink dat die mens se denke ' $n$ eie aard het, met 'n eie inisiatief en bepaaldheid en op ' $n$ eie wyse funksioneer, kreatuurlik, onselfgenoegsaam. Maar u kan die denke losstel van God, u kan die denke teenoor God verselfstandig, u kan die denke verabsoluteer - dan praat ons van die outonomie van die denke. Ons verwerp die outonomie van die denke.

34 ["Ek het toe ek in Toronto was in 1973 'n veerticntal skole onderskei wat vandag stry om die vraag wat wetenskap is."] In sy oorspronklike rede het Stoker dit as cen van die "pragtigste" wetenskaplike probleme beskryf. 
Elke wetenskaplike wat die outonomie van die denke huldig, huldig ' $n$ mensbeskouing. Agter alle wetenskappe sit daar 'n mensbeskouing. ${ }^{35}$

\subsubsection{Antropologiese agtergrond}

\subsubsection{Die mens as kosmiese wese}

Die eerste probleem is die vraag 'wat is die mens?' U kan dit van talle kante benader. Ek benader dit net kortliks vanuit twee gesigspunte. Ek wil dit baie tegnies stel: die mens is 'n kreatuurlike kosmiese wese; hy behoort tot die aarde; hy is 'n aardse wese; hy is geheel en al kosmies; sy wetenskap is ook kosmies. Daarom kan ons saam met Nietzsche sê: "Niks wêrelds, niks kosmies, ag ek is vreemd". 36

Jy kan maar let op die ooreenkoms tussen stof, plant en dier aan die een kant en die mens aan die ander kant en die plek en rol van die mens.

Teoloë mag van my verskil, maar so lees ek die Bybel: hiernamaals sal die mens nie 'n engel wees wat in die hemel lewe nie; hy sal 'n aardse wese wees, op 'n nuwe aarde as kosmiese wese woon - 'n wese met 'n kosmies verheerlikte liggaam waarop 'n nuwe hemel neergedaal het. $U$ mag die aardsheid van die mens en daarmee die aardsheid van die wetenskap; die kreatuurlike kosmiese aard van mens en wetenskap nooit uit die oog verloor nie.

\subsubsection{Die mens as beeld van God}

Aan die ander kant is die mens die enigste wese wat as beeld van God geskape is. Selfs die engele word nie die beeld van God genoem nie; bulle is dienende geeste. Die mens gesien as die beeld van God moet die grondslag wees vir ons antropologie en ons moet daarvoor ons volle oopheid hê. ${ }^{37}$ Ek kan hier baie voor-

35 Dit sluit aan by Stoker (1969:252): "Elke wetenskap (Teologic, Wysbegeerte en vakwetenskap) het met die mens te doen. Dit is die mens wat wetenskap bcoefen, wat o.a. (reg of verkeerd) vir die wetenskap sy kenbronne uitkics, sy docl bepaal en sy grense vasstel ... Weens hierdic 'persoonlike faktor' in die wetenskapsbeoefening is elke wetenskaplike verplig om hom oor sy mensbeskouing wat aan sy wetenskapsvorming ten grondslag lê, te verantwoord."

36 Stoker het die huidige krisis met betrekking tot die mensbeskouing in die wetenskap sterk gestel. In Stoker (1965) skryf hy byvoorbceld: "Dic huidige mens het homself verloor in dié sin dat hy cintlik nic meer weet wic en wat hy is en wat sy rol en bestemming is nie. Juis hierdic stand van sake maak dit ons insiens van aktuele belang vir dic Wysgerige Antropologic (en per implikasic ook vir dic Vakwetenskaplike Antropologieč) ...".

37 Vgl. sy standpunte oor die betekenis van die mens as becld van God (Stoker, 1965). 
beelde gee. In verband met beeld van God bedoel ek beeld van God nie in die engere teologiese $\sin$ van heiligheid, geregtigheid en regverdigheid nie. Ek bedoel dit in die omvattende sin van analogie. Orals waar die mens met God analoog is, daar het jy die beeld van God.

Laat ek analogie verduidelik: ons gaan uit van twee onderskeidings - ooreenstemming en verskil. Waar $u$ verskil soek binne ooreenstemming, daar het $u$ variante, variasies, variabiliteit. Maar omgekeerd, waar u ooreenstemmings soek binne ' $n$ verskeidenheid en die verskeidenheid vooropstel, daar kry $u$ analogie. Ek gee net 'n paar voorbeelde: die mens en sy portret; dit mag ' $n$ sprekende portret wees, maar daardie portret kan nie asemhaal nie, daardie portret kan nie praat nie; nie eet nie. Daar is ' $n$ analogie - daar is ' $n$ wesenlike verskil en ooreenstemming. God is heerser en die mens heers ook. Orals waar ons 'n analogie tussen mens en God vind, die mens as beeld van God sien, daar sien u die wesensverskil tussen mens en dier - iets wat my telkens in die sielkunde en die filosofie opgeval het. Waar jy ' $n$ wesensverskil tussen mens en dier sien, daar kom meteen die beeld van God ook tot openbaring. Ek kan dit ongelukkig nie hier in besonderhede uitwerk nie. ${ }^{38}$

\section{Die menslike hart}

\subsection{Wat is die hart van die mens?}

In verband met die oopheid van hart, wil ons ons afvra waar ons moet begin. Ons begin met die menslike handelinge. Met menslike handelinge bedoel ek daardie handelinge wat by die dier ontbreek, handeling wat verantwoordelik is, toerekenbaar is; daardie handelinge waarin meteen die beeldskap Gods tot uitdrukking kom. Onder daardie handelinge in ruime sin verstaan ek ook denke as handeling; ook waardering as handelinge; ook dit is toerekenbaar en verantwoordelik.

As ons dan wil ondersoek dat "uit die hart is die uitgange van die lewe", dan begin ons met die menslike handelinge, dan interpreteer ons die handelinge in 'n omvattende sin, maar dit staan dieper - hierdie handelinge is 'n uiting van die menslike hart. 39

38 Vanweë tydsbeperking kon Stoker nie verder toelig hoedanig dic volgende stellings dic wesensverskille tussen mens en dier illustreer nic: "Die mens is bewus van iets. Die dier is bewus van iets. Die dier se bewus wees van iets is radikaal anders as die menslike bewus wees van iets."

39 [Ek gaan die onderskeid van hele en totale mens nic met $u$ behandel nic. Ek wil nct sê u beoefen wetenskap as hele mens en nic net met u teoreticse doel nicl. 
Op die vraag 'Wat is die hart?' het ek die betrokke literatuur deurgegaan en het ek vier groepe antwoorde gekry: (a) Die hart is die hele mens, die hele menslike persoon, die selfheid van die mens; (b) die hart is 'n deel of 'n faset, of 'n funksiegroep van die mens; dit is die menslike gees of die menslike siel of die menslike inbors of sy gemoed of sy gevoel; (c) die hart is die diepste van die mens, die diepste aspek van menswees, die fontein van die innerlike lewe van die mens, die bron van alle geestelike krag, die setel van kennis, gevoel en wil; die ek, die kern van sy persoon-wees, van sy menslike bestaan, die mees oorspronklike in die mens, die konsentrasiepunt van die mens; die eksistensie, die diepste dryfveer van die menslike handelinge, die uitgang van die hele menslike lewe, die sentrum van die mens; (d) die hart is die sentrale plek waartoe God hom rig; die hart is die religieuse lewenswortel van die mens; die religieuse wortel van die menslike bestaan.

\subsection{Die hart as onsigbare misterieuse grootte}

Geeneen van die uiteensettinge hierbo bevredig nie. Sommige is heeltemal verkeerd, sommige is nader aan die waarheid. Ek wil hier vir Augustinus aanhaal, en dan wat hy in verband met tyd sê: "As iemand vir my vra of ek weet wat die hart is, dan sê ek 'ja seker!' Maar as iemand vir my vra om te sê wat my hart is: 'Nee, ek kan dit nie sê nie'."

Die hart is 'n onsigbare, misterieuse grootte in die mens, daarom volg ek in hierdie opsig graag die voorbeeld van Dooyeweerd. Onder hart, sê hy, verstaan hy wat Gods Woord met hart bedoel en almal wat Christelik-gelowig is, weet wat Gods Woord bedoel, en dit is vir ons doel, dink ek, voldoende. Maar die naaste is dat die hart in een of ander sin die diepste grond van menslike handelinge is en, in verband met ons probleem, die diepste grond van wetenskapsbeoefening.

\subsection{Die oopheid van hart in verband met oopheid van wetenskap}

\subsubsection{Twee fundamentele probleme}

As ons nou die oopheid van die wetenskap gaan behandel, dan kom ek voor verskillende probleme te staan, maar daar is net twee wat ek hier in $u$ midde lê. Hierdie twee fundamentele probleme is die volgende: In die Bybel word gestel dat uit die hart die uitgange van die lewe is, maar wat presies word daarmee bedocl? In die tweede plek: Waar jou skat is, daar sal jou hart wees. Wat hou hicrdie Bybelse formulering in? In hierdie lesing beperk ek my net tot die eerste omskrywing van die hart. Die eerste uitspraak behandel ek onder wat ek die orde van skepping noem: die prinsipiële sin van die hart as die uitgang van die lewe. 
Die tweede uitspraak - Waar jou skat is, daar sal jou hart wees, behandel ek onder die orde van sondeval en verlossing ${ }^{40}$. Jy kan jou skat verkeerd kies en dan kom die hele probleem van verval en stryd in die wetenskap in sig. Ons beperk ons net tot die eerste, naamlik dat die hart die uitgange van die lewe is.

\subsubsection{Die eerste probleem: Uit die hart is die uitgange van die lewe}

Ek moet sê (ek hoop hier is teoloë in ons midde), dat ek in verskillende opsigte teleurgesteld is met ons nuwe Afrikaanse Bybelvertaling, wat probeer om in die moderne idioom die Bybel te vertaal en dan, volgens my, misgrepe maak. Ek het dit in die vorige lesing aangetoon en kan nog ' $n$ paar aantoon. Hier wil ek net die volgende aantoon: Daar staan in die Nederlandse Bybel: Uit die hart is die uitgange van die lewe; in die Engelse Bybel: "Out of the heart are the issues of life" - "the issues", die uitinge, die uitspruitsels. Die Afrikaanse Bybel maak dit: "Uit die hart is die wortels van die lewe". Nou sou ek gesê het dit is vir my Grieks, maar ongelukkig ken ek Grieks. Dus sê ek dit is vir my Japannees, ek verstaan niks daarvan nie.

Ons het hier te doen met die inisiatief: uit die hart is die uitgange van die lewe. Ek gaan weer begin deur te stel dat uit die hart is die toerekenbare en verantwoordelike handelinge van die lewe. Die tweede vraag bly egter watter bydrae hierdie uitgangspunt tot die wetenskap maak. Ons stel hier die essensiële probleem in verhouding van hart tot die lewe; meer in besonder van hart tot wetenskapsvorming. In hierdie opsig sluit ek aan by die toerekenbare verantwoordelike handelinge van die mens. Ek vestig u aandag op die woorde toerekenbaar en verantwoordelik, want daaroor gaan ek my eers aan die einde van die lesing verantwoord.

\subsubsection{Die menslike handelinge}

As ek na die handelinge kyk wat toerekenbaar en verantwoordelik is, dan is hulle legio. Ek glo nie in 'n klassifikasie nie, veral nie logiese klassifikasie nie, behalwe as 'n skematiese hulpmiddel. Die werklikheid is in sy verskeidenheid so geweldig groots en in soveel verhoudinge dat ek nie die verskeidenheid van die wêreld en ook nie menslike handelinge in 'n logiese skema kan vasknyp nie nie.

As ek dan vra na die hooftipes van menslike handeling, dan vra ek nie in 'n sin na die klassifikasie na die mees algemene handelinge waaronder ek die ander handelinge verder kan klassifiseer nie. As ek vra na die hoofhandelinge, dan vra ek na daardie dinge wat in elke besondere handeling op sy eie wyse weer tot uit-

40 Vir sy prinsipiële onderskeid tussen dic orde van die skepping en die orde van sondeval en verlossing, kyk Stoker (1970a:236 c.v.). 
drukking kom - fundamentele handelinge. En as ek dit vra - eienaardig genoeg dan vra ek meteen na die probleem van menslike vryheid. Daarom wil ek met die probleem van menslike vryheid begin om hierdie hoofhandelinge te verduidelik. ${ }^{41}$

\subsubsection{Menslike vryheid en menslike handelinge}

Ek gee hier net 'n kort opsomming van hoe ek vroeër die vryheidsprobleem behandel het. Ek noem net die bestryding van determinisme, indeterminisme en selfdeterminisme in die begin. 42 Ek het die negatiewe opvatting van vryheid verwerp: vryheid as onafhanklikheid, ongekondisioneerdheid, onbepaaldheid. Ek het gevoel ons moet probeer om vryheid positief te sien; vryheid positief in sy positiewe selfgetuienis. ${ }^{43}$ Is vryheid nie heerskappy nie? ${ }^{44}$ Die dier is geen heer nie, maar die mens is heer. God het die mens as heer in sy skepping geskape, as kreatuurlike kosmiese god, die heer van die here. Is heerskappy nie vryheid nie? As u dit noukeurig analities gaan ondersoek: die mens-heer, be-heer, be-heers en dan het $\mathrm{u}$ die menslike heer-likheid in sy twee betekenisse: Heer-gelykheid en heer-glorie, want dit is ' $n$ glorie van die mens om 'n heer op aarde te wees, analoog met die heer-skappy van God. Heers die mens nie ook in die kuns, in ekonomie nie. As my eggenote soggens die stoffies en twakkies van die tafel vee, is dit nie ook heers nie? Daar word geheers oor daardie stoffies en twakkies om die tafel skoon te maak. Maar die mooiste voorbeeld om vryheid as heerskappy te sien, is die wiegeling, die baba in die wieg. Ek het by Karl en Charlotte Bühler

41 Vir 'n bibliografiese samevatting van die vernaamste werke van Stoker oor menslike vryheid, kyk Stoker (1967:157 - voctnoot).

42 ["Ek het tot 'n sekere hoogte Klaas Dijk en Willem Gcesink nagevolg, maar hulle was vir my onbevredigend. Ek het my voorgangers nagevolg, veral ook uit dic kring van dic Vrije Universiteit, wat vryheid van dic wet stel, vryheid en wetsoortreding as teenstelling maak Dit het my ook nie bevredig nic. Dit is te uitwendig, te formecl; ons kry geen innerlike insig in vryhcid nic"].

43 ["Ek hoop nic dat ck sommige van u hier skok nie: dic eerste impuls om vryheid positicf te sien, het ek gekry van daardie geniale, intrigrerende Godloënaar Nietzsche. Nietzsche stel vryheid nie teenoor wetsoortreding nie. Hy stel vryheid teenoor slawerny, en dic vrye is dic heer, die slaaf is die onvrye. Afgesien van dic kontckste waarbinne hy dit gesien het - wat ek nic aanvaar nie - het ek mysclf afgevra: Maar kan dit nic vryheid wees nie? Is vryheid nic heerskappy nic?'].

44 Volgens Stoker (1938:18) is die positicwe sin van vryheid - vryheid wat die hele menslike persoonlikheid omvat - geleë in dic koninklike opdrag wat God aan dic mens gegec het, naamlik dat $\mathrm{Hy}$ sal heers oor dic hele aarde. Hicrdic opdrag om te heers sluit selfbehecrsing in. Dic mag van die mens oor die natuur, om natuurbeheerser te wees, is 'n opdrag van God. Dit is die bestemming, dic grond-idec van menswees. Heerskappy oor die aarde, waar dic mens nóg dic aarde, nóg homself geskape het, kan nie onafhanklik wees nic, maar is tog vryheid (vgl. ook Stoker, 1967:162-167 en Raath, 1985:209 e.v.) 
veral hulle boeke oor taalpsigologie intens geniet. As 'n kindjie neurie en sing lalalala, mamama, tatata, ${ }^{45}$ is daar nie 'n klein heer-tjie aanwesig wat leer om sy stemapparaat te be-heers sodat hy later kan praat nie?

\subsubsection{Vryheid as heerskappy}

Vryheid is in die eerste plek heerskappy in 'n positiewe $\sin .{ }^{46}$ Is wetenskaplike vryheid nie ook heer-wees, heer-wees van u vak nie? Moet u nie die literatuur onder die knie hê en heer wees van u gebied nie? Moet u nie u waarneming, $u$ denke, $\mathrm{u}$ kenne be-heer nie? Moet u nie u veld van ondersoek be-heer nie? Moet $\mathrm{u}$ in $\mathrm{u}$ probleemstelling en $\mathrm{u}$ metodekeuse en die kriteria-erkenning nie heer wees, nie be-heer nie? Is wetenskaplike heerskappy nie die eintlike vryheid van wetenskap in 'n positiewe sin nie?47

Vryheid as heerskappy is ook oopheid: oopheid in u beheersing van die veld van ondersoek, oopheid in u denke, kenne, metodes, oopheid in die velde wat $u$ ondersoek ensovoorts.

45 [U weet, dit is ' $n$ spel, dit is ' $n$ heer-like spel en as u weet wat spel is, dan sit daar iets groots in, want dan moct u ook dink aan wat Popma van spel maak, dic homo ludens: dic mens is in sy diepste wese ' $n$ spelende mens; spelende voor Gods aangesig. Daar het $u$ reeds spel. Maar wat gebeur daar? Met hierdic aparte gencurie-spel word geartikulcer. Die kind leer om elke klank afsonderlik uit te spreck: a, t, k, p, ens. En dit is dic hecr-likc verskil met die dier. Dic lecu brul vanaf sy geboorte tot dic end van sy lewe, daar is geen artikulasie nie. Maar om te artikuleer moet die kind heerskappy oor sy stem-apparaat hê en clke moontlike stemklank wat hy kan voortbring, apart van die ander ecn stel om later in foncem-kombinasies te verbind, later in aanduidinge tot name en woordc te vorm."]

46 Hiervan verklaar Stoker (1964:441): "In sy verhouding tot dic kosmos (stof, plant, dier en mens) héćrs die mens. Met betrekking tot God is menslike hecrskappy uitgesluit. Daar dién hy ... Die diens van God vereis onderworpenheid (gehoorsaamheid) aan behorenseise (w.o. die wet van dic Here), anders was dit nie verantwoordelik en het diens sy orde nie gehad nie. Ook die diens van God bevat ' $n$ taak... As ons menslike heerskappy in sy verhouding tot dic kosmos as sy vryhcid mag opvat, waarom sou menslike vryheid in sy verhouding tot God nie diens wees nie?"

47 Tot hierdic analise van menslike vryheid het Stoker grootliks gekom deur gebruikmaking van die 'fenomenologiese metode'. Op hierdic punt in sy lesing verwys hy soos volg daarna: "Kollegas het my dikwels beskuldig dat ck 'n fenomenoloog is omdat ck onder prof. Scheler, ' $n$ fenomenoloog, gestudecr het. Die opvatting van wese en wesenhede van Scheler, Husserl en dié mense het ek nooit oorgeneem nie. Vir my is die fenomenologie net 'n kwessie van metode deur te kyk, jou $\propto \ddot{c}$ oor dic dinge tc laat gaan en te onderskei wat radikaal onderskcic is en hoe dic radikaal onderskcie saamhang. Ek nocm dit dic diafaneroticsc metode. Dit is diafeneroties, of as u wil fenomenologies as ck my oog so oor al dic menslike handelinge laat heengaan ...". 


\subsubsection{Vryheid as skep}

As ek in die tweede plek na die mens kyk, dan sien ek dat hy iets nuuts tot stand bring. Ek wil hier net een voorbeeld neem. Ek het jare gelede gelees dat bye 5000 tot $6 / 7000$ jaar gelede min of meer op dieselfde wyse hulle selle gebou het as wat hulle vandag doen. Nou vra ek: kyk 'n bietjie na die wonings wat die mens gebou het - wonings van die primitiefste volke, dwarsdeur die eeue heen tot vandag toe; en nie die wonings nie - kyk na die kerkgeboue, die hotelle, industriegeboue; kyk na enige soort gebou. Hier word telkens iets nuuts tot stand gebring en telkens iets nuuts met 'n nuwe styl. Hierdie totstandbrenging van die nuwe - mag ek dit skepping noem? ${ }^{48}$

God skep. Die teoloë sê Hy het hemel en aarde uit niks geskape. Dit is vir hulle verantwoordelikheid. Ek hou meer van wat Cornelius van Til, daardie groot Calvinis van Amerika, sê: "God did not create heaven and earth out of nothing. He created heaven and earth into nothing." Dit is veel dieper, veel pragtiger; dit is veel magtiger.

God se skepping is absoluut; dit is die skep van iets wat in 'n radikale sin nog nie daar was nie. Maar by die mens as beeld van God bring hy ook die nuwe tot stand. Neem weer die klanke van u stem. U kan dit verander in taal, in woorde, in name, in sinne. Dis iets nuuts. Neem die klanke wat musiekinstrumente maak. U kan dit verander in simfonieë of watter kunsstukke ook al. Dis iets nuuts. Neem die tegniek: 'n bouwerk is iets nuuts. Neem die hele geskiedenis: in elke nuwe tydsgewrig bring die mens iets nuuts tot stand. Die mens is 'n kosmiese kreatuurlike skepper wat kragtens die bevoegdhede en die moontlikhede hom geskenk, telkens die nuwe te voorskyn bring.

In die tweede plek wil ek in 'n positiewe sin sê: menslike vryheid - ook in die wetenskap - is skepping; ${ }^{49}$ menslike vryheid is kreatiwiteit. Orals waar die mens optree met sy verbeelding sien hy nuwe dinge en pak hy nuwe dinge aan en doen hy dit met nuwe metodes. Ook in die wetenskap: nuwe probleme, nuwe probleemstellings, nuwe probleemontdekkinge, nuwe probleemhanteringe, die hele probleemskepping van nuwe teorieë by nuwe ontdekkinge/uitvindinge. Vorming gebruik jy orals: in skeikunde, plantkunde, dierkunde; orals praat jy van vorming.

Vgl. ook Stoker (1946:10).

49 |"Dan doen dit my hart goed as ck by John Murray - hy was vrocër 'n senior lektor aan Wits $\mathrm{cn}$ is toc in die dertigerjare na dic Universiteit van London waar ck hom gaan opsoek het - lees waar hy skryf: 'Human freedom is creativity". 'n Woord soos 'creativity' het ons nic in Afrikaans nic. U moct my die anglisisme vergewe: menslike vryhcid is kreatiwileit." 
Maar hierdie vorming wat toerekenbaar en verantwoordelik is, is skepping. Ook hier het ons 'n uiting van die hart, die mens as skeppende wese kragtens sy menslike bestaan. Hier is ook sprake van die oopheid van die skepping.

\subsubsection{Vryheid as sorg}

In die derde plek, as ek weer my oog so oor al die handelinge laat gaan - is dit nie opvallend dat die mens sorg nie? ${ }^{50}$ Laat ons ons maar net tot mense bepaal daar is moedersorg, daar is volksorg, daar is maatskaplike sorg, politieke sorg. Is kunsskepping nie ook sorg nie? Is enigiets wat die mens doen nie ook sorg nie? Die maak van tuine en parke, is dit nie sorg nie? Ek sal nog een voorbeeld neem: die huidige tegniek met sy geweldige heerskappy en sy geweldige skeppingskrag veroorsaak besoedeling. Vandag word geprotesteer teen die besoedeling van water en aarde en lug wat allerlei organismes laat uitsterwe. Wanneer besoedel word, word nie gesorg nie en die mens protesteer daarteen. Die hele wêreld is aan die mens se sorg toevertrou en in die mens se sorg - deur God aan hom toevertrou - kom die rentmeesterskap van die mens tot uiting. Die mens is aan God verantwoording verskuldig vir wat hy doen. Heerskappy is sorg, kreatiwiteit is sorg. Sorg is nie net iets vir die ekonomie nie, die mens is in alles rentmeester wat sorg vir die hele wêreld wat God aan die mens toevertrou. Waarom sou ek nie kon sê vryheid is sorg nie?

\subsubsection{Vryheid as diens}

In die vierde plek is die hooftipe vryheid, die hoof-fundamentele handeling die diens van God.51 Dit is een van die merkwaardigste dinge dat die mens God kan ken, dat God Hom aan die mens kan openbaar in Woord en werk, en hy in God kan glo, God kan aanspreek, God kan loof, prys, dank, smeek. Ek weet nie of u die geweldige dieptes wat daarin opgesluit lê so insien soos ons dit behoort te sien nie. Maar is hierdie diens van God in engere en ruimere sin, as godsdiens, as religie, nie ook vryheid nie.

50 Die grondlyn van vryheid as sorg het Stoker reeds in 1945 ontwikkel. Hy skryf (1945:14)

"Hierdie hecr-op-aarde wees, hicrdic behering, hicrdic hecrskappy, hierdic eg-menslike Heerlikheid is sy vryheid en dit is as sodanig 'n afglans van dic Heerlikheid, van dic absolute vrymag Gods. Die boer wat plocg, dic kunstenaar wat kuns skep, die vrou wat versorg, die gelecrde wat wetenskap bou, ja elke mens wat as mens handel, hecrs oor cn op hierdic aarde Gods. Dit is sy vryheid."

51 Stoker (1964:441) beklemtoon dit dat vryheid as diens van God nic vernederend vir dic mens is nie. Vryheid as diéns van God is slegs vir hom (byvoorbeeld dic humanis) "wat soos God wil wees", vemederend met ander woorde vir hom wat God en mens as gelyke groothede op dieselfde vlak wil stel. 
Die hooftipes van vryheid - ook wetenskaplike vryheid - is diens van God. Heerskappy en kreatiwiteit en sorg en diens van God is die vier hooftipes van vryheid, wat saamgevat moet word deur die omstandigheid dat God die mens moontlikhede skenk. As ek praat van skenk, dan dink ek aan Jaspers. Jaspers sê as ek mondig word, dan vind ek myself aan myself geskenk. Dit is 'n pragwoord daardie. Ek sien dit nie binne sy kontekste nie, maar ek vind my denke is my geskenk, my kenne is my geskenk, my wil is my geskenk, al die moontlikhede is my geskenk. Maar aan my is ook geskenk alle moontlikhede van die wêreld: om die natuur tot kultuur te verander; om van klank 'n taal te maak, of van verf skilderye te maak. Al die moontlikhede van die werklikheid is my geskenk, en hierdie moontlikhede wat jou geskenk is, wat jy by heerskappy kry, by sorg kry, by kreatiwiteit kry, by diens van God kry, is jou geskenk as 'n eis, as 'n vraag en dan is die mens se inisiatief 'n antwoord. Hy antwoord op dit wat God hom geskenk het om te doen. Heidegger, Sartre, Jaspers is verkeerd om te sê die mens is oorspronklik vraer, hy moet eindeloos vra, geen vraag mag deur hom bedek wees nie. Nee, die mens is primêr antwoorder, 52 antwoorder op al die moontlikhede wat God hom skenk met sy heerskappy, met sy kreatiwiteit, met sy sorg, met sy diens, en die antwoorde moet so wees, soos hy dit behoort te doen. Die antwoorde moet aan die vrae beantwoord, sodat die vrae van God, die roep wat uit die werklikheid tot jou kom, aan jou inisiatief as antwoorder voorafgaan. Die menslike inisiatief is antwoord aan dit wat God hom stel.

\section{Die diepere harte-uitings as heers, skep, sorg en diens van God}

\subsection{Liefde en kennis}

Uit die hart is die uitgange van die lewe, en uit die hart kom voort heerskappy, kreatiwiteit, sorg, diens van die Allerhoogste. Dit is die uitinge van die hart. Maar hierdie uitinge van die hart is nie die diepste nie, hulle is gefundeer in dieper uitinge, en ons moet tot daardie diepere uitinge deurdring. Ek gaan met 'n eienaardige probleem begin waanmee ek reeds geworstel het toe ek my proef-

52 In 'n vierde stadium van sy denkontwikkeling het Stoker tot die insig gekom dat menslike vryheid (hecrskappy in horisontale verband en vertikaal gegrond in die diens van God) antwoord is (as antwoording): "Vraag het sonder antwoord, antwoord sonder vraag geen sin nic. Wie die mens egter (soos die cksistensiewysbegeerte) as oorspronklike vraer sien, werp hom op sy vraende censaamheid en verlatenheid terug, en skeur daarmee mens en wêreld asook mens en God (en daarmee antwoord en vraag) uiteen. Maar wic dic mens as oorspronklike antwoorder op dic vrac vanuit dic kosmos sien soos hulle hul oorsprong vind in God, die Rocper, en daarmee sien hoe die menslike antwoord (vryheid) aan die hom gestelde vrac beantwoord, kyk meteen hoe dic mens en wêreld asook mens en God innig verenig is, soos vraag en antwoord tesame 'n korrelasionele cenheid vorm" (Stoker, 1960:192-193) 
skrif ${ }^{53}$ aangepak het. Dit het veral gegaan oor die gewete, die probleem van die vertroubaarheid van die kennis van die gewete. As die gewete vir jou sê jy is skuldig, kan jy dit vertrou? In die deurdink van daardie probleem het ek in aanraking gekom met die probleem van kennis en liefde.

Vir die Grieke is liefde die gevolg van kennis; is liefde in kennis gefundeer, by Plato word liefde gewek by die aanskouing van die grootse ideë in hulle glorieuse reinheid. Dan kom die Christendom en draai hierdie siening net om; Augustinus sê byvoorbeeld: wille, handele, voele of enigiets wat die mens doen, is in liefde gefundeer. Dan sê hy dit eksplisiet: kenne en wille is in liefde gefundeer, liefde gaan aan kenne en wille vooraf.

Nou wil ek aan u die vraag stel in verband met die positiewe vryheid wat ek behandel het: is heerskappy nie in liefde gefundeer nie? Is kreatiwiteit, sorg of diens van God nie in liefde gefundeer nie? Is liefde nie 'n grondkrag van die menslike hart nie, of as jy wil - 'n grondkrag van sy siel - ('n Urquelle $e^{54}$ noem die Duitsers dit) wat ten slotte ten grondslag lê aan alles wat jy doen en laat. Liefde ... ek kan nie sê wat liefde is nie. Ek wil hier 'n uitdrukking gebruik wat Heidegger in verband met swem gebruik, maar dit toepas op die woord liefde. Wat liefde is, leer ek nie ken deur 'n verhandeling oor liefde te lees nie. Wat liefde is, leer ek ken deur lief te hê, dis al metode. Ek veronderstel u weet wat liefde is as ek verwys na moederliefde, volksliefde, liefde vir skoonheid, kuns, tegniek, liefde vir dit, liefde vir dat. Dan moet u onmiddellik met hierdie ostensiewe aanduidinge sien hoe universeel bestaan naasteliefde, maar dit hinder my soms 'n bietjie dat veral gereformeerde teoloë so skrikkerig is om selffiefde tot sy reg te laat kom. Die Bybel sê jy moet jou naaste liefhê soos jouself, maar jyself of ekself is geskape as beeld van God.55 Ek moet hierdie beeld in ere hou. Ek moet die skyn bewaar en mag nie my naam in oneer laat val nie. Ek moet die beeldskap van God in my tot sy reg laat kom, waardeer, liefhê. Ek kan nog baie meer voorbeelde gee. Ook die roeping wat God my gegee het, moet ek hartstogtelik liefhê as my roeping. Liefde is universeel, nie alleen liefde vir God nie, maar ook liefde vir die mens in al sy verskeidenheid en verbondenheid. Maar dan veral ook liefde vir die wêreld: jy moet die wêreld liefhê. Daar staan in die Bybel: "God het die wêreld so lief gehad dat $\mathrm{Hy}^{56}$..." ensovoorts. Waar die

53 Stokcr, 1925.

54 'n "Eerste oorsprong"

55 Kyk Stoker se "Die betekenis van 'dic mens as beeld van God' vir dic Wysgerige Antropologie" in 1967:83 e.v.

56 Johannes 3:16: "Want so lief het God die wêreld gehad dat Hy sy eniggcbore Scun gegec het, sodat eikeen wat in Hom glo, nie verlore mag gaan nie, maar die cwige lewe kan hê." 
Bybel sê jy moet die wêreld haat, bedoel hy die sondige wêreld, die afgevalle wêreld. Maar die wêreld as 'n skepping van God, wat tot God behoort, wat onder die sorg van God staan en deur Hom in stand gehou en bestier word, daardie wêreld in sy tealiteit, in sy karakter van Goddelike oorsprong, daardie wêreld moet jy liefhê: jy moet plante liefhê, jy moet diere lieflề, sodat die liefde universeel is. Agter alles wat die mens doen en laat, agter heerskappy is liefde. Alle heers is in liefde gefundeer; alle kreatiwiteit is in liefde gefundeer; alle sorg is in liefde gefundeer; die diens van God is in liefde gefundeer, en ook die liefde vir die wetenskap. Op hierdie punt het ons te doen met die kostelike probleem waarmee Augustinus, Blaise Pascal, Max Scheler (my promotor), F.J.J. Buytendijk en talle eksistensie-wetenskaplikes geworstel het. ${ }^{57}$

Die grondprobleem is dat kennis in liefde gefundeer is; dat liefde die fundamentele harte-uiting is van alles wat die mens doen en laat, maar veral ook van kenne: 'n liefde met jou hele hart, jou hele verstand; ook liefde met jou hele verstand as jy God dien: nie net met jou hele hart, hele gemoed, hele siel en met al jou kragte nie.

Deur die liefde waarin die wetenskaplike kenne gefundeer is, gaan die hart oop vir sy funksie, taak en belange, maar ook vir dit waannee hy in kontak kom. Met hierdie oopgaan van die werklikheid deur die liefde, gee die liefde hom oor aan die belange wat onties in die werklikheid aanwesig is; bind die liefde. Liefde is openend en verbindend - ook in die wetenskap. 58

\subsection{Geloof}

\subsubsection{Die sekerheidsmotief in die wetenskap}

Daar is 'n tweede diepere uiting van die hart waarin heerskappy, kreatiwiteit, sorg en diens van God gefundeer is. Ek begin met die sekerheidsprinsipe in die wetenskap. Ek het nie nagegaan in hoeverre die sekerheidsprinsipe by die Grieke eksplisiet gefungeer nie. Ek het veral in die modeme denke 'the principle of certainty' nagegaan. By Descartes is dit net metodologies. By Hume word die soek

57 |"Ek sĉ opsetlik eksistensic-wetenskaplikes. Daar is nic net cksistensic-filosowe nic, daar is eksistensic-teoloc, siclkundiges, taalkundiges ens. Eksistensic-wetenskaplikes en fenomenoloë het kostelike dinge oor die licfde gevind, daar gelaat of hulle reg of verkecrd is."'

58 |"En dan is hierdic licfde ten slottc, in dic allerlaaste sin, ook weer antwoord: die licfde van die mens tot God is ' $n$ antwoord op die liefde van God as wederliefde. Maar God het in sy liefde dic wêreld geskape, in sy licfde die wêreld aan dic mens geskenk on geopenbaar en deur dit alles in sy liefde die mens geroep. En dic mens se rocpingsvervulling is ook weer, omdat alles in liefde gefundeer is, antwoord op wat hy moet doen."] 
na sekerheid met sy twyfelmetode amper asemberowend. Dan kry jy die positivisme vanaf Comte en andere. 59

\subsubsection{Die persoonlike aard van sekerheid}

Dit bring my by my probleem: ek lees by verskillende wetenskaplikes - ek dink veral aan Herman Bavinck - dat sekerheid subjektief en waarheid objektief is. Die woorde subjektief en objektief het vandag sewe of agt verskillende betekenisse. Subjektief en objektief het onbruikbaar geword. Ook Dooyeweerd gee sy eie betekenisse daaraan.

In plaas van subjektief wil ek praat van persoonlik. Sekerheid is iets persoonliks. As ek die woord saaklik in ' $\mathrm{n}$ baie ruim sin, of liewers die 'ontiese', neem, dan is die ontiese dit wat die waarheid openbaar - sê maar die ontiese waarheid.

Bavinck sê sekerheid is in waarheid gefundeer; dit is nie die sekere wat iets waar maak nie, maar dit is die ware wat jou seker maak, en dit is my kritiek hierop. Maar wat dan van ons verhouding tot die waarheid? Dan kom ek tot die interessante insig: alle sekerheid rus in 'n vertroue, in die trou van dit wat vertrou word; alle sekerheid rus in die vertroue van die ware, in die vertroue van die ontiese.

\subsubsection{Geloof fundeer sekerheid}

As u bietjie verder gaan: Wat is vertroue? Geloof. Alle sekerheid rus in geloof. Geloof is een van die mees fundamentele kragte van jou sielelewe, van die uitinge van jou hart. Ek gaan nie sê hoe geloof ten grondslag lê aan heerskappy nie - as u dit nie glo nie, kan u nie heers nie. U moet glo dat geloof ten grondslag lê aan kreatiwiteit, aan sorg, aan diens van God. Ek neem geloof in 'n ruime sin: selfs 'n humanis kan nie 'n humanis wees as hy nie aan sy menswees as absoluut glo nie. Alles rus in geloof.

\subsubsection{Geloof as grondslag/grondakte vir alle handelinge/vir alle vryheid}

Die wetenskap begin in geloof sodat geloof naas liefde ' $n$ fundamentele uiting van die hart is - ' $n$ uiting wat ten grondslag lê aan al jou doen en late. 'n Dier kan nie

59 ["Ek dink aan alle positivistiesc wetenskaplikes ... Dic huidige cksistensicfilosofie het as religieuse grondmoticf die radikale onmoontlikheid om van blote kontingensic tot $\sin$ te kom. Die religieuse moticf wat ck by dic positiviste en in ' $n$ vervattende vorm by dic neopositiviste vind, is 'n motief waarin hy nie net seker wil wees van sy waarneming, van sy denke, problcemstellinge, metodes ensovoorts nie, maar waar hy gehecl en al uit eic mag, eie krag en eie outarkic, sonder geloof, sonder voorwetenskaplike kennis, homself wil verseker van wat scker is; ' $n$ radikale sclfversekerde sckerheid. Dit is dic religieuse moticf van die positivisme en u vind dit in sy twce pilare: waarncming en denkc."। 
glo nie. God met sy alwetendheid is radikaal bo die dier verhewe en die mens is in sy allerdiepste wese afhanklik, kreatuurlik. Die mens is 'n gelowige wese alleen die mens kan glo.

Ek kan nou verder die universaliteit van die geloof aantoon in alles wat jy doen en laat. Ek kan die rol van die geloof in die wetenskap vir u uitwerk; want $u$ moet $u$ denke glo. As 'n chemikus met 'n eksperiment 'n stukkie lakmoespapier in sy hand hou en sien dis rooi en hy glo nie dis rooi nie, kan hy nie verder gaan nie. Aan sy problematologie, metodologie, kriterialogie van die wetenskap lê geloof ten grondslag. Dit is fundamenteel, dis 'n geloofskrag uit die diepste van die mens; uit die hart.

Deur te glo gaan die waarheid aan u oop; deur te glo gaan die veld wat $u$ ondersoek aan u oop; deur te glo kan $u$ al beter en al noukeuriger die verskeidenheid in $u$ veld van ondersoek onderskei; oopheid van geloof ook in u denke, ensomeer.

\subsection{Hoop}

\subsubsection{Wetenskap as avontuur}

Met die derde fundamentele uitgang van die lewe wil ek eindig. Ek wil op 'n direkte manier begin. Ek het in baie werke gelees wetenskap is ' $n$ avontuur. Professor Stafleu, ek het dit geniet dat u nou die aand ook gesê het wetenskap is 'n avontuur. Ek wil dit breër stel: alles wat die mens doen en laat, is ' $n$ avontuur 'n avontuur in die sin dat die mens met liefde en geloof sy take tegemoetgaan en sy take aanpak, maar nie weet wat die uitkoms is nie; die uitkoms nie ken nie. U waag, en met 'waag' bedoel ek hier waag in 'n Christelike sin. Alle heerskappy is avontuur, alle kreatiwiteit is avontuur. As ' $n$ kunstenaar ' $n$ nuwe simfonie wil begin of as 'n skilder daardie wonderlike glimlag van 'n Mona Lisa op die doek wil vasvang - dis 'n avontuur: hy waag iets, maar hy is onseker of hy dit sal regkry, ensovoorts.

$\mathrm{U}$ sorg is ' $\mathrm{n}$ avontuur en $\mathrm{u}$ diens van God is ' $\mathrm{n}$ avontuur. Wetenskap is ook ' $\mathrm{n}$ avontuur. As ' $n$ student met sy referaat besig is, waag hy iets. Ek sê altyd aan my studente die heerlikste waagstuk is as hul eksamen skryf. Dit is éérs 'n avontuur, dan is jy in die smeltkroes - jy weet nie wat die uitslag gaan wees nie; as $u$ ' $n$ M.A.-verhandeling of ' $n$ proefskrif aanpak, weet $u$ nie presies waar $u$ gaan uitkom nie. In die wetenskap impliseer alle probleme wat $u$ vind, dat $u$ waag. ${ }^{60}$ Dit is ' $n$ waagstuk om die probleem te probeer oplos, ensomeer. Maar wat is die grond-

60 ["In die wetenskap, in alle probleme wat u mag vind, is dit 'n waagstuk om die probleem te stel. Probleme word oorspronklik gevind, daarna gestel."। 
slag van die avontuur om by daardie diepste uiting van die hart te kom? Dink byvoorbeeld aan bergklimmers aan die voet van een van die hoogste berge waarvan hulle die kruin wil bereik. Hulle het die geloof, hulle het die liefde, maar hulle het ook die hoop dat hulle dit sal regkry. 'n Tweede voorbeeld: in die huweliksbevestiging van prins Philip en prinses Diana het die aartsbiskop gesê: "En nou begin julle avontuur." Elke paartjie wat trou, het sy planne vir die toekoms, het sy ideale vir die toekoms, en nou waag hulle om dit te verwesenlik as twee mense wat tesame alle lotgevalle van hulle lewe wil deel tot die dood hulle skei - dis 'n avontuur.

\subsubsection{Hoop as voortstuwende $\mathrm{krag}$}

As 'n huwelikspaar nie die hoop het nie, sou hulle nie die huwelik onderneem het nie. Hulle avontuur veronderstel hoop. Die bergklimmers sou nooit daardie kruin probeer bereik het as hulle nie die hoop gehad het nie. So lê hoop aan heerskappy ten grondslag, lê hoop ook aan kreatiwiteit ten grondslag, lê hoop aan sorg ten grondslag en lê hoop aan diens van God ten grondslag. Heerskappy, kreatiwiteit, sorg en diens, as uitinge van die hart, is gefundeer in die diepste uitinge van liefde, geloof en hoop.

\section{Samevattend: liefde, geloof en hoop as grondkragte in die hart}

Ek het gesê dat ons in al hierdie gevalle met menslike handelinge te doen het wat toerekenbaar en verantwoordelik is - handelinge wat wesensverskillend is van die dier. Wat bedoel ek met toerekenbaarheid en verantwoordelikheid? Ek gaan probeer om dit in twee sinne te sê. Die eerste is die ontsettende woord kies. Ek weet nie waarom daar van Protestantse kant, maar veral van Calvinistiese kant soveel huiwering is om te erken dat die mens kan kies nie.61 Die teoloë maak die almag van God wat albestierend is so absoluut en alomvattend dat hulle die menslike moontlikheid van keuse al meer en meer inkrimp sodat daar byna niks daarvan oorbly nie. In die Bybel loop twee lyne. Die eerste lyn is dat God alles bestier - geen haar sal van jou hoof af val as God dit nie wil nie. Dan die ander lyn: die mens is verantwoordelik vir sy val; hy en hy alleen sal die skuld dra. Aan sy val en die keuse van sy val het God geen skuld nie. Dit is twee waarhede wat die menslike verstand te bowe gaan. Dis 'n superdoks.

61 Kyk ook Stoker (1960:182): “Dat die mens werklik kan kies, wéćt ck uit my 'crvaring' Dit is geen illusie dat ek in dic verlede kon kies, in die hede kan kies en in dic tockoms sal kan kies nie. My slegte gewete het geen sin as ek in die verlede nic anders kon gehandel het nie ... Bowendien kan die mens sonder kicsvryheid nie tocrekenbaar wees en verantwoordelik handel nie. Ook (oortrecbare wette), menslike deugde en pligte het sonder 'n kiesvryheid geen sin en bestaansmoontlikhcid nie." (Vergelyk ook Stoker, 1945 en 1946.) 
Vanaf die begin van my akademiese loopbaan het ek altyd met teoloë en andere gestry: ek kan kies - ek kan hier opstaan, ek kan nou hier afsluit; ook u kan luister of $u$ kan doen wat $u$ wil. In alles wat $u$ doen en laat, is die moontlikheid van keuse daar. Maar u moet dié gedagte nou verdiep in twee ontsettende opsigte: in die eerste kan u na Sartre gaan - daardie geweldige intrigerende geniale ateïs. Hy sê die mens kan kies. Die mens moet kies, hy kan nie anders as om te kies nie. Selfs om nie te kies nie is om te kies. Die mens is tot kies gedoem. En lees jy Sartre se ander werke, dan klink dit asof hy sê die mens is tot keuse verdoem. Hier het $u$ die hart van die eksistensialisme.

Afgesien van Sartre se oordrywinge en sy verkeerde kontekste is dit waar dat die mens kan kies. My probleem was: die mens kan kies, die oopheid het hy daar, maar die oomblik wanneer hy kies, dan is sy keuse gedetermineerd. Dan kan jy sê: dit was sy motiewe, dit was sy intensies, dit was sy wense, dit was sy waarderinge en dit en dat het alles die keuse bepaal. Die keuse is handeling.

Ek het met hierdie probleem van keuse na Totius en Willie Snyman, twee van ons bekwaamste teoloë, gegaan, en gevra hoe ons dit moet verstaan. Totius sê toe: "Daardie moontlikheid van keuse wat die Skrif bied, moet jy sien as 'n oop moontlikheid; maar net as moontlikheid - dit is nog nie realiteit nie. Die oomblik wanneer dit oorgaan na realiteit, na die keuse, na die werklikheid, dan kan jy sien watter bepaalde faktore daar was."

Hierdie oorgang van 'n oop moontlikheid om te kies tot die keuse self is een van die diepste misteries van menswees in die kosmos - ' $n$ misterie waarop ons geen antwoord het nie.

Ek aanvaar die mens kan kies en volgens Romeine 1:19 en 20 staan die mens teenoor die presensie van God - 'n teenwoordigheid waarteenoor hy vandag nog kiesend staan. Die mens kon in die paradys selfs téén God gekies het. Deur te kies is die mens toerekenbaar, kan hy rekenskap gee van wat hy doen. Sartre sê deur te kies is al die gevolge van die mens se keuse op sy rekening, en ondat sy gevolge oneindig in die heelal is, is die hele wêreld byna sy skuld.

Daar is egter die ander kant van die saak. Die mens kan nie net kies nie, hy mag dit kies en dát mag hy nie kies nie; hy behoort dír te kies en dát behoort hy nie te kies nie. Daar is belange-orde, daar is 'n verskeidenheidsorde, daar is 'n Goddelike orde in die wêreld wat in die samehang van die verskeidenheid uitkom; wat in die belange en verhoudinge van al die dinge uitkom. As u daardie orde-karakter probeer ontleed dan kom u by die wet en die norme uit. Die mens moet hom in die orde inpas waarvolgens die aarde geskape is. Hy behoorl die orde te verdiep, te bevorder, mag dit nie verbreek nie, mag nie chaos inbring nie. 
Hier kry u die ontsettende probleem dat die mens kan kies tussen wat hy behoort te doen en wat hy nie behoort te doen nie. Hy kan kies dit wat hy nie behoort te doen nie of dit wat hy behoort te doen. Hierdeur het die mens nie 'n toerekeningskuld nie, hier het hy ook 'n verantwoordelikheidskuld - staan hy skuldig voor God. Met hierdie laaste dimensie - die mens as antwoordende op die roep van God wat hy in die hele skepping universeel aan die mens stel; waarop hy met ' $n$ oop keuse moet anwoord as mede-arbeider Gods - om die bestemming wat God met die aarde beoog ordelik te verwesenlik - daar het u die laaste probleem van die menslike faktor in die wetenskap, uitgaande van ... "uit die hart is die uitinge van die lewe".

\section{Bibliografie}

\section{Boeke en monografieë}

RAATH A.W.G.. 1985. Menslike vryheid in konteks en perspektief. Bloemfontein : UOVS (D. Phil-proefskrif.)

STOKER H.G. 1925. Das Gewissen. Gepubliseerde proefskrif Bonn : Cohen

STOKER H.G. 1927a. Teistiese Wysbegeerte. Die Vaderland. s.a.

STOKER H.G. 1927b. Enkele grondbeginsels van 'n teistiese filosofie. Woord en Geest, $21.10 .1927-16.12 .1927$.

STOKER H.G. 1932-1933. Die nuwere wysbegeerte aan die Vrije Universiteit. Die Wagtoring, Febr. 1932-Junie 1933.

STOKER H.G. 1933a. Die nuwere wysbegeerte aan die Vrije Universiteit. Pretoria : De Bussy.

STOKER H.G. 1933b. Die Wysbegeerte van die Skeppingsidee. Pretoria : De Bussy.

STOKER H.G. 1938. Die idee van menslike vryheid. Jaarboek van die Suid-Afrikaanse Akademie, XVIII:9-32.

STOKER H.G. 1941. Iets oor Calvinisme Die Gereformeerde Vaandel, VI (3):79-83.

STOKER H.G. 1945. Die waarheid maak vry. Die Kerkblad, 6.04.1945:13-15

STOKER H.G. 1946. False Viewpoints of Human Freedom \& The Essence of Human Freedom. (VSA-lesing, ongepubliseer.)

STOKER H.G. 1960. Die mensbeskouing in die wysbegeerte. (Die verantwoordelike vryheid van die mens) - Interfakultêre lesing. Koers, 27 (7 en 8). 180-196.

STOKER H.G. 1964. Menslike vryheid. Koers, 31 (7-8): 426-448.

STOKER H.G. 1965. Die betekenis van "die mens as beeld van God" vir die Wysgerige Antropologie. (In Homo Viator - Feesbundel aangebied aan dr. C.K. Oberholzer. p. 2047.)

STOKER H.G. 1967. Oorsprong en rigting. Deel I. Kaapstad : Tafelberg-Uitgewers

STOKER H.G. 1969. Beginsels en metodes in die wetenskap. Johannesburg : De Jong.

STOKER H.G. 1970a. Oorsprong en rigting. Deel II. Kaapstad : Tafelberg-Uitgewers

STOKER H.G. 1970b. Die aard en die rol van die reg. Publikasiereeks van die RAU A36, Johannesburg. 


\section{Tydskrifte}

Die P.U. Kaner, 12.09.1975.

Die P.U. Kaner, 19.06.1981.

Die Wapad, 25,09.1981.

\section{Ander bronne}

H.G. Stoker-versameling (HGSV): Dokumentêre nalatenskap van prof. H.G. Stoker in besit van sy seun, prof. P.H. Stoker, en kleinseun, ds. H.G. Stoker (jnr). 
